\title{
CHARACTERIZATION OF ACTINOMYCETES STRAIN TA3.A03 ISOLATED FROM MARINE SEDIMENT OF VIETNAM
}

Do Thi Tuyen*, Do Thi Thu Hong

Vietnam - Russia Tropical Centre

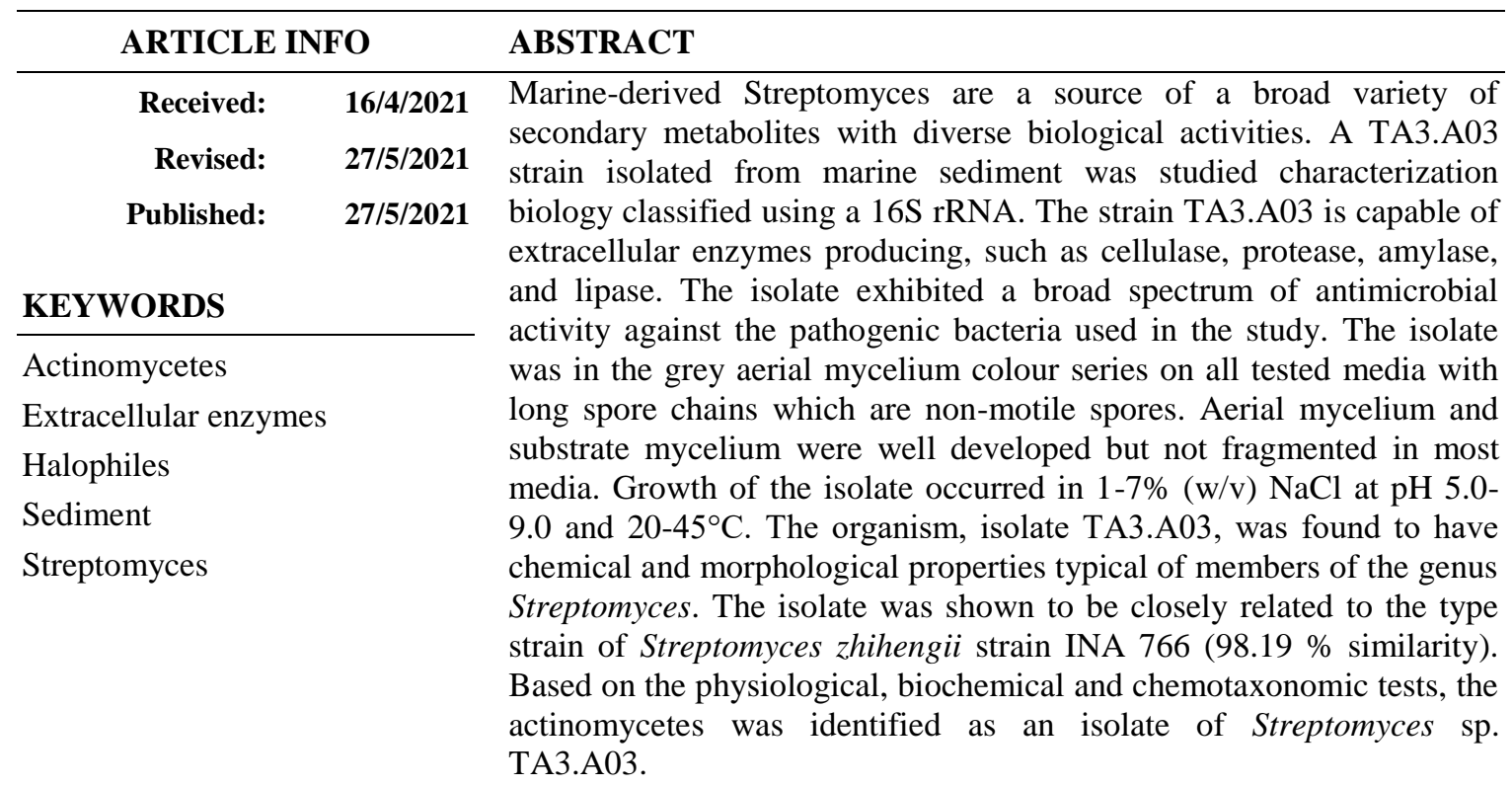

\section{ĐặC ĐIỂM CHỦNG XẠ KHUẨN TA3.A03 \\ PHÂA LÂPP TƯ TRẢM TÍCH BIỂN VIẸT NAM}

Đỗ Thị Tuyến*, Đỗ Thị Thu Hồng

Trung tâm nhiệt đới Việt Nga

\begin{tabular}{|c|c|c|}
\hline \multicolumn{2}{|c|}{ THÔNG TIN BÀI BÁO } & \multirow{3}{*}{$\begin{array}{l}\text { TÓM TẮT } \\
\text { Xạ khuẩn thuộc chi Streptomyces có nguồn gốc từ biển là nguồn cung } \\
\text { cấp nhiều hợp chất chuyển hóa thứ cấp với các hoạt tính sinh học đa } \\
\text { dạng. Chưng xạ khuẩn TA3.A03 phân lập từ trầm tích biển được }\end{array}$} \\
\hline Ngày nhận bài: & $16 / 4 / 2021$ & \\
\hline Ngày hoàn thiện: & $27 / 5 / 2021$ & \\
\hline Ngày đăng: & $27 / 5 / 2021$ & nghiên cứu các đặc điểm sinh học và định danh dựa trên trình tự gen \\
\hline & & 16S rRNA. Chủng TA3.A03 có khả năng tổng hợp các enzyme ngoại \\
\hline \multicolumn{2}{|l|}{ TÙ KHÓA } & bào đa dạng (cellulase, protease, amylase, lipase). Chủng thể hiện hoạt \\
\hline \multicolumn{2}{|l|}{ Xạ khuẩn } & khảo sát. Chủng có khuẩn ty khí sinh màu xám trên tất cả các môi \\
\hline \multicolumn{2}{|l|}{ Enzyme ngoại bào } & trường thử nghiệm, cuống sinh bào tử dài và bào tử không di động. \\
\hline \multicolumn{2}{|l|}{ Ua mặn } & Khuẩn ty khí sinh và khuẩn ty cơ chất phát triển tốt và không bị phân \\
\hline \multicolumn{2}{|l|}{ Trầm tích } & nhánh. Chủng phát triến ở các điều kiện $1-7 \%$ (w/v) $\mathrm{NaCl}$; pH 5,0-9,0 \\
\hline \multirow{5}{*}{\multicolumn{2}{|c|}{ Streptomyces }} & sinh hoá điển hình của các thành viên thuộc chi xạ khuẩn \\
\hline & & Streptomyces. Kết quả so sánh với trình tự gen tương đồng trên \\
\hline & & Genbank cho thấy chủng TA3.A03 có liên quan chặt chẽ với chủng \\
\hline & & INA 766 thuộc loài Streptomyces zhihengii (độ tương đồng 98,19\%). \\
\hline & & $\begin{array}{l}\text { Dựa trên các xét nghiệm sinh lý, sinh hóa và hóa học, chủng xạ khuấn } \\
\text { nghiên cứu được định tên là Streptomyces sp. TA3.A03. }\end{array}$ \\
\hline
\end{tabular}

DOI: https://doi.org/10.34238/tnu-jst.4381

${ }^{*}$ Corresponding author. Email:tuyendodhkh@gmail.com 


\section{Introduction}

Marine habitats, due to their ecological pressure, including the competition of space and predation, and physical properties such as salinity, temperature and pressure variations, led marine microorganisms to develop unique secondary metabolites with various biological activities to survive in this highly demanding ecosystem. However, the marine actinomycetes strains from marine habitats have received little attention compared with their terrestrial counterparts even though there is evidence that they are a potentially rich source of new drug candidates [1]. This can be exemplified by marine sediments, which are nutrient-rich habitats, harboring considerable organism biodiversity with metabolic and genetic potential to develop bioactive secondary metabolites. A large number of marine actinobacteria have been isolated and characterized from various locations around the world in recent times [2], [3]. Strains of marine actinomycetes having potential of secreting extracellular enzymes (protease, lipase, cellulase, amylases,...), which work well in alkaline $\mathrm{pH}$ range, tolerating high concentrations of organic solvents in their environment have been reported in the last few years [4], [5]. Their ability to produce antibiotics has also been explored [3], [4]. Many marine actinomycetes are good candidates for bio-surfactant production [6]. In this context, marine actinobacteria are a promising source of novel bioactive compounds, especially from underexplored areas, providing an alternative means for secondary metabolite discovery.

Streptomyces is the largest genus in the phylum Actinobacteria with over 650 validly named species. Members of the genus remain a unique source of pharmacologically active compounds; hence, the interest in screening them for novel bioactive products has been continued. Taxonomically diverse marine actinomycetes are widely distributed in the marine ecosystem and some require seawater for growth [4]. The selective isolation of Streptomycetes from marine habitats can be enhanced when selective media are prepared with seawater, artificial seawater, or with deionised water supplemented with $3 \%$, w/v NaCl [7], [8]. Such approaches have led recently to the selective isolation of novel Streptomyces species from marine sediments, seawater, and marine sponges [2], [5]. Doralyn S Dalisay et al. [7] isolated 49 marine sediments samples collected in the temperate cold waters from British Columbia, Canada as a valuable source for new groups of marine-derived Streptomyces with antimicrobial activities and obtained 186 Streptomyces isolates, 47 of which exhibited antimicrobial activities. Chemical analyses revealed structurally diverse secondary metabolites, including four new antibacterial novobiocin analogs [7]. Streptomyces orientalis and S. aureomonopodiales exhibited good biosurfactant activity at high temperature, $\mathrm{pH}$ and salt concentration [6]. The ethyl acetate extract of Streptomyces sparsus VSM-30 may have antibacterial, antifungal, and antioxidant activities due to the presence of secondary metabolites in ethyl acetate extract [8]. Tran et al. [9] isolating 16 Streptomyces strains from marine water and sediment samples showed the antibacterial activity and produced extracellular enzymes like cellulase, amylase and protease with the salt tolerance up to 7\%.

Research on marine actinobacteria from Viet Nam's Truong Sa Islands is very scanty and to date, these Island resources have not been properly explored to identify novel microorganisms with potential biological properties. This study was conducted to classify the actinomycetes strain TA3.A03 isolated from marine sediments of West Reef in Viet Nam's Truong Sa Islands and identify the potential sources for industrial and pharmaceutical by products. Actinomycetes classification is based on colonial and cell morphology, as well as similarity in the 16S rRNA gene.

\section{Materials and methods}

\subsection{Materials}

Sampling of actinomycetes: The actinomycetes strain TA3.A03 was obtained from the Biotechnology Laboratory, Vietnam - Russia Tropical Centre. This strain was previously isolated 
from the marine sediment of Vietnam. Strain TA3.A03 was maintained over the surface of SCA agar slants supplemented with $3 \%$ of sea salt (w/v) and stored with glycerol stocks $20 \%$ at $-20^{\circ} \mathrm{C}$.

Phytopathogens: The phytopathogens, namely, Staphylococcus aureus, Bacillus subtilis, Listeria spp., Pseudomonas aeruginosa, Escheria coli, Samonella spp. were provided by the Biotechnology Laboratory, Vietnam - Russia Tropical Centre.

\subsection{Methods}

\subsubsection{Isolation and maintenance of the strain}

Strain TA3.A03 was isolated from a sediment sample from West Reef in Viet Nam's Truong Sa Islands. This strain was maintained on medium SCA (1.0\% soluble starch, $0.03 \%$ casein, $0.2 \%$ $\mathrm{K}_{2} \mathrm{HPO}_{4}, 0.2 \% \mathrm{KNO}_{3}, 0.005 \% \mathrm{MgSO}_{4}, 0.002 \% \mathrm{CaCO}_{3}, 0.001 \% \mathrm{FeSO}_{4}, 2.0 \%$ agar (pH 7), with $\mathrm{NaCl} 3 \%$ ) and incubated at $28^{\circ} \mathrm{C}$ for 14 days. The isolate was purified and maintained on slants of SCA medium, glycerol stocks of the isolates were also prepared and stored at $-20^{\circ} \mathrm{C}$ for further analysis [3], [10].

\subsubsection{Morphological, cultural and physiological characteristics}

Morphological, biochemical, cultural and physiological characterization of the actinomycetes isolates was performed as recommended by the International Streptomyces Project (ISP) which were described by Shirling and Gottlieb Cultural characteristics were observed on ISP media, all of which were supplemented with $3 \%(\mathrm{w} / \mathrm{v}) \mathrm{NaCl}$, after incubation at $28^{\circ} \mathrm{C}$ for 14 days. The ISCC-NBS Colour Charts Standard Samples No. 2106 was used to determine the colours of aerial mycelium, substrate mycelium and diffusible pigments. Cells were Gram-stained and examined under the microscope. Micromorphological characteristics were observed with a magnification of $100 \mathrm{X}$ or $400 \mathrm{X}$ using cultures grown on ISP 4 medium at $28^{\circ} \mathrm{C}$ for 25 days. Growth at different temperatures $\left(4,10,20,28,37,45,50^{\circ} \mathrm{C}\right.$ ), at $\mathrm{pH} 4.0-12.0$ (at intervals of 1.0 $\mathrm{pH}$ unit) and in the presence of $0-10 \% \mathrm{NaCl}(\mathrm{w} / \mathrm{v})$ were determined. Carbon sources utilisation was tested using ISP 9 medium supplemented with a final concentration of $1 \%$ of the carbon source tested [11], [12].

\subsubsection{Screening of extracellular enzymes production}

The actinomycetes species were analyzed for their ability to produce various extracellular hydrolytic enzymes. Degradation tests for gelatin, cellulose, starch and Tween 80 were conducted by using Gauze 1 medium (with $3 \%(\mathrm{w} / \mathrm{v}) \mathrm{NaCl}$ ) as basal medium. The isolates were grown on substrate agar plates $(1 \%, \mathrm{w} / \mathrm{v}$, cellulose, gelatin, starch and Tween 80$)$ for the determination of cellulase, protease, amylase and lipase activity. The plates were incubated for 7 days at a temperature of $28^{\circ} \mathrm{C}$ and detected enzyme activity. The confirmation tests of hydrolytic enzymeproducing ability were conducted by using the method of disc diffusion [8].

\subsubsection{Antimicrobial activity}

Spores from a mature slant culture of the actinomycete strain were inoculated aseptically into a $250 \mathrm{~mL}$ Erlenmeyer flask containing $100 \mathrm{~mL}$ broth SCA medium, with $\mathrm{NaCl} 3 \%$ and incubated under submerged fermentation conditions at $28^{\circ} \mathrm{C}$ for $96 \mathrm{~h}$ at $180 \mathrm{rpm} / \mathrm{min}$. Cell-free supernatant of fermentation broth was recovered by centrifuging it at $5000 \mathrm{rpm} / \mathrm{min}$ for $15 \mathrm{~min}$. Ethyl acetate was added to the supernatant in 1:1 proportion and the mixture was agitated for $10 \mathrm{~min}$. The solvent layer containing the antibiotic substance was separated from the solution and it was further centrifuged at $5000 \mathrm{rpm}$ for $15 \mathrm{~min}$.

The extracted crude substance was assayed in triplicate for their antimicrobial activity against S. aureus, B. subtilis, P. aeruginosa, E. coli, Samonella spp., Listeria spp. by agar diffusion plate assay using MPA medium for the antimicrobial assay, respectively. The extracted crude substance $(100 \mu \mathrm{L})$ was added to each well and the antimicrobial activity was observed after $24 \mathrm{~h}$ 
of incubation at $28^{\circ} \mathrm{C}$ for bacteria and the inhibition zone formed around the disc was measured with a transparent ruler in millimeter $(\mathrm{mm})$. A sterile disc impregnated with ethyl acetate was used as control [4], [10]. All the assays were performed in triplicate.

\subsubsection{Phylogenetic analyses}

For the extraction of genomic DNA, strain TA3.A03 was grown in $\mathrm{SC}$ broth at $28^{\circ} \mathrm{C}$ for 7 days. Genomic DNA extraction was carried out by Kit GeneJET Plant Genomic DNA Purification (Thermo Scientific). PCR amplification of the 16SrRNA gene was conducted using forward (27F - (5'-AGAGTTTGATCMTGCCTCAG-3')) and reverse (1492R - (5'TACGGYTACCTTGTTACGACTT-3')) primers performed as previously described by $\mathrm{Vu}$ et al. [5]. The PCR-apparatus was programmed as follows: 5 min denaturation at $94{ }^{\circ} \mathrm{C}$, followed by 35 amplification cycles of $1 \mathrm{~min}$ at $94{ }^{\circ} \mathrm{C}, 1 \mathrm{~min}$ of annealing at $55^{\circ} \mathrm{C}$, and $2 \mathrm{~min}$ of extension at $72{ }^{\circ} \mathrm{C}$, followed by at $10 \mathrm{~min}$ final extension at $72{ }^{\circ} \mathrm{C}$. The purified PCR product of approximately $1300 \mathrm{bp}$ was purified and sent for sequencing at 1st Base Laboratories Sdn. Bhd., Malaysia. The 16S rRNA gene sequence was analyzed and compared to the public nucleotide database using the NCBI BLAST website.

\section{Results and discussions}

\subsection{Characterization of potent actinomycetes strain TA3.A03}

Table 1. Characterization of potent actinomycetes strain TA3.A03

\begin{tabular}{lccc}
\hline \multicolumn{1}{c}{ Characterization } & Strain TA3.A03 & Characterization & Strain TA3.A03 \\
\hline Gram's stain & Gram-positive & Cultural on different media \\
(Aerial mycelium/Substrate mycelium) & Grey/ brown \\
Colony & $\Phi 3-4 \mathrm{~mm}$ & ISP1 & Grey/ faint brown \\
Melanin production on ISP medium 6 & Non & ISP3 & Grey/ brown \\
Spore chain morphology & RF & ISP4 & - \\
Number of spores /chain & 10 to 25 spores & ISP5 & - \\
NaCl concentration for growth (w/v) & $1-7 \%$ & ISP6 & Grey/ brown \\
\multicolumn{1}{l}{ Growth on sole carbon source $(1+, \mathrm{w} / \mathrm{v})$} & ISP7 & Grey/ brown \\
Glucose & + & ISP9 & Degradation of \\
Lactose & + & Cellulose & + \\
Maltose & + & Gelatin & + \\
Saccharose & + & Starch & + \\
Galactose & + & Tween 80 & + \\
Rhamnose & - & Antimicrobial & + \\
Ribose & - & activities & + \\
\hline
\end{tabular}

Strain TA3.A03 was isolated and maintained on a modified SCA medium with $\mathrm{NaCl} 3 \%$. This strain was observed as aerobic, Gram-positive actinobacterium to form branched substrate mycelium and to grow well on ISP 1, ISP 3, ISP4, ISP7, ISP9 media but not on ISP 5, ISP 6 media and no melanin production was observed on ISP 6 media (Table 1). The aerial mass colour was observed to be in the grey colour series on all tested media. The aerial mycelium of this strain was well developed but not fragmented and, at maturity, formed short chains of spores (Figure 1). Investigations of 7-day-old cultures of strain TA3.A03 revealed that the isolate shared the same morphological characteristics as members of the genus Streptomyces. Strain TA3.A03 can grow at a temperature range of $20-45^{\circ} \mathrm{C}$ (optimum $28^{\circ} \mathrm{C}$ ), a pH range of 5-10 (optimum 7 8 ) and can tolerate $\mathrm{NaCl}$ up to $7 \%$. Strain TA3.A03 was found to degrade casein, gelatin, starch, tween 80. The capability of strain TA3.A03 to utilise different carbon sources was tested on ISP 
9 medium. The strain shows good growth on D-galactose, D-glucose, maltose, lactose and sucrose but cannot utilise rhamnose, ribose as a sole carbon source.

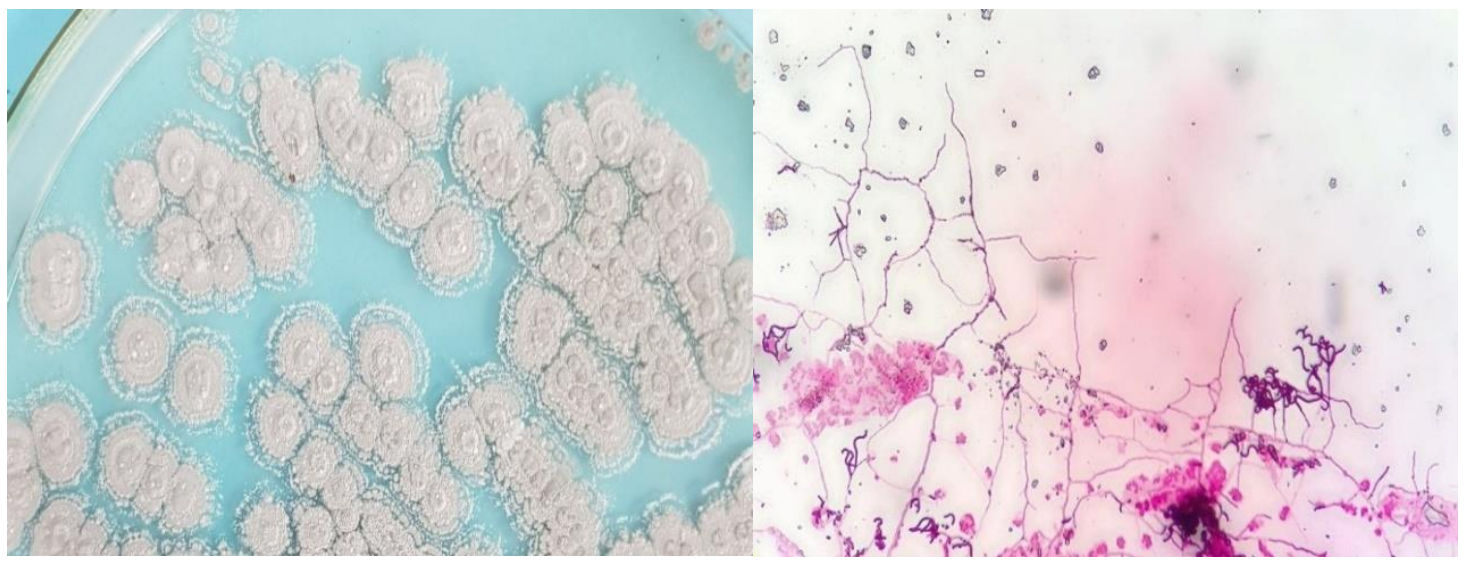

Figure 1. Color of the aerial mycelium and the spore chain morphology of strain TA3.A03 grown on ISP agar medium for 7 days at $28^{\circ} \mathrm{C}$ at a magnification of $400 \mathrm{X}$

Growth survival studies of TA3.A03 isolate also accomplished to stand in varied $\mathrm{NaCl}$ and $\mathrm{pH}$ levels. Based on previous reports, the majority of the actinomycetes species isolated from marine sediments were moderate alkaliphilic and moderate halophilic [4], [6], [7]. To cope with external stress, these actinomycetes have developed adaptive metabolic features to survive under extreme conditions. Streptomyces orientalis and S. aureomonopodiales, alkaliphilic actinobacteria were reported to grow optimally at $\mathrm{pH} 9-10$ [6]. Streptomyces zhihengii strain INA 766 was isolated from Pramuka Island, Kepulauan Seribu, Indonesia. This actinomycetes train was growth at 0 $9 \%\left(\mathrm{NaCl}, \mathrm{w} / \mathrm{v}\right.$ ) (optimum 1-3\%), $10-40{ }^{\circ} \mathrm{C}$ (optimum $25-30^{\circ} \mathrm{C}$ ) and $\mathrm{pH}$ 6-9 (optimum pH 7). It gave positive results for antibacterial activity and hydrolysis of starch, cellulose and gelatin [13]. Chen et al. [8] also reported a halophilic marine actinomycete, Streptomyces sparsus VSM-30, isolated from sediment.

\subsection{Screening for enzyme production}

Table 2. Enzyme activity of actinomycetes (halo zone in $\mathrm{mm}$ ) isolated from compost

\begin{tabular}{|c|c|c|c|c|}
\hline \multirow{2}{*}{ Actinomycetes } & \multicolumn{4}{|c|}{ Enzyme activity (mm) } \\
\hline & Cellulase & Amylase & Protease & Lipase \\
\hline TA3.03 & $24 \pm 0.67$ & $14.67 \pm 1.11$ & $25.67 \pm 1.78$ & $20.33 \pm 1.11$ \\
\hline Cellulase & Amylas & & & \\
\hline
\end{tabular}

Figure 2. Enzyme activity of actinomycetes strain TA3.03

Screening of isolates was performed to determine their capability to yield industrially important enzymes such as amylase, protease, cellulase, and lipase. The selected substrates were added with the minimal mineral medium for the production of various enzymes because most of the enzymes are inducible. After incubation, plates were flooded with respective indicator solutions and the development of a clear zone around the growth of the organism was documented as positive results for enzyme activity [7]. Extracellular hydrolytic activity and the 
halo zone around the isolated strain $(\mathrm{mm})$ were presented in table 2 and figure 2 . The result showed potent extracellular hydrolytic enzymes all tested (cellulase, protease, amylase and lipase). These enzymes are very important for the hydrolysis and recycling of nitrogen and carbon trapped in an insoluble form.

From marine water and sediment samples collected from Hai Phong, Thanh Hoa, and Nghe An provinces, Tran et al. isolated 16/35 Streptomyces strains showing the ability to produce extracellular enzymes like cellulase, amylase and protease with the salt tolerance of up to $7 \%$, and the good growth on the medium with different $\mathrm{C}$ resources and $\mathrm{pH}$ 5-9. This strain also has antagonistic ability against $S$. aureus, E. coli, and B. cereus [9]. A total of 13/26 actinobacterial strains were isolated from the marine sediments collected from various sites of Port Blair Bay to produce all 8 extracellular enzymes of industrially important enzymes such as amylase, protease, gelatinase, lipase, DNase, cellulase, urease and phosphatase [3].

\subsection{Actinomycetes and their antagonistic properties against the selected Phytopathogens}

The antimicrobial activity of strain TA3.03 was screened against three Gram-positive ( $S$. aureus, B. subtilis, Listeria spp.) and three Gram-negative (P. aeruginosa, E. coli, Samonella spp.) bacteria. The antibacterial efficacy of ethyl acetate extract from TA3.A03 strain against clinical pathogens is depicted in table 3 and figure 3.

Table 3. Antiphytopathogenic effect of selected actinomycetes (Zone of inhibition in mm) on radial growth of tested bacteria

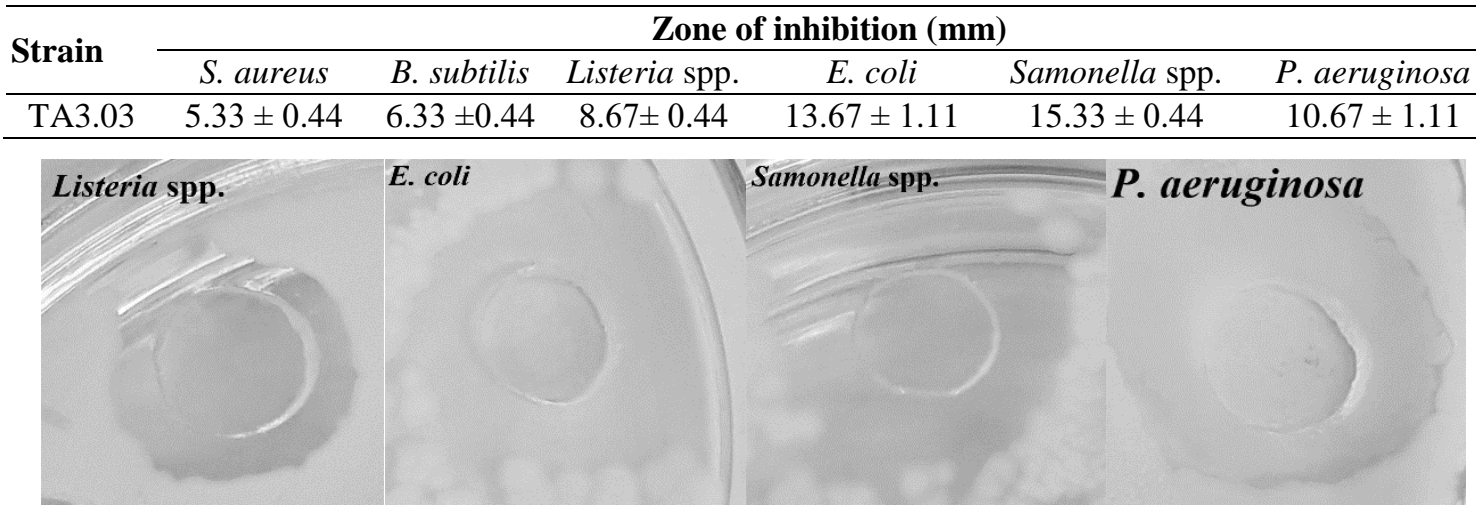

Figure 3. Antibacterial activity of actinomycetes strain TA3.03 on radial growth of tested bacteria

The result in table 3 showed that TA3.A03 strain inhibited the growth of all the test organisms, exhibited appreciable inhibitory activity against both Gram-positive and Gram-negative bacteria used in the study. This suggests the broad-spectrum nature of the bioactive secondary metabolite from marine Streptomyces. A similar study by Meena et al. [3] reported the broad-spectrum nature of antibiotics from Streptomyces against various microbial pathogens, inhibited the growth of both pathogenic bacteria and fungi. Tran et al. [9] evaluated marine Streptomyces strains with antibacterial activity against some pathogenic bacteria showing the antagonistic ability against $S$. aureus ATCC 12222, E. coli ATCC 25922, and B. cereus ATCC 25923. Among 47 of 186 marine-derived Streptomyces isolated from sediments of British Columbia, Canada produced new secondary metabolites with antimicrobial properties, against methicillin-resistant $S$. aureus (MRSA) [7].

\subsection{Identification results}

The organism, isolate TA3.A03, was found to have chemical and morphological properties which are typical of members of the genus Streptomyces. To determine the phylogenetic position, the purified PCR product of approximately $1300 \mathrm{bp}$ was determined (Figure 4). Comparison of the sequence with the corresponding 16S rRNA gene sequences retrieved from GenBank and 
phylogenetic tree of the TA3.A03 strain inferred from GenBank sequences demonstrated that strain TA3.A03 was a member of the genus Streptomyces with high sequence similarity with the type strain of Streptomyces zhihengii strain INA 766 (98.19\% similarity), Streptomyces werraensis F24 (97.18\% similarity) (Figure 5).

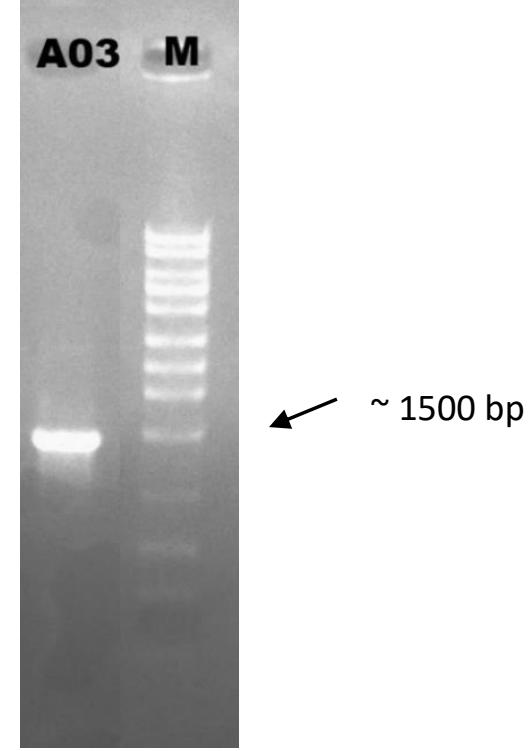

Figure 4. Agarose gel electrophoresis (1\% agarose) of PCR amplified products using PCR primer (27F-1492R) of strain TA3.A03. Lane M, 1 kb DNA size marker.

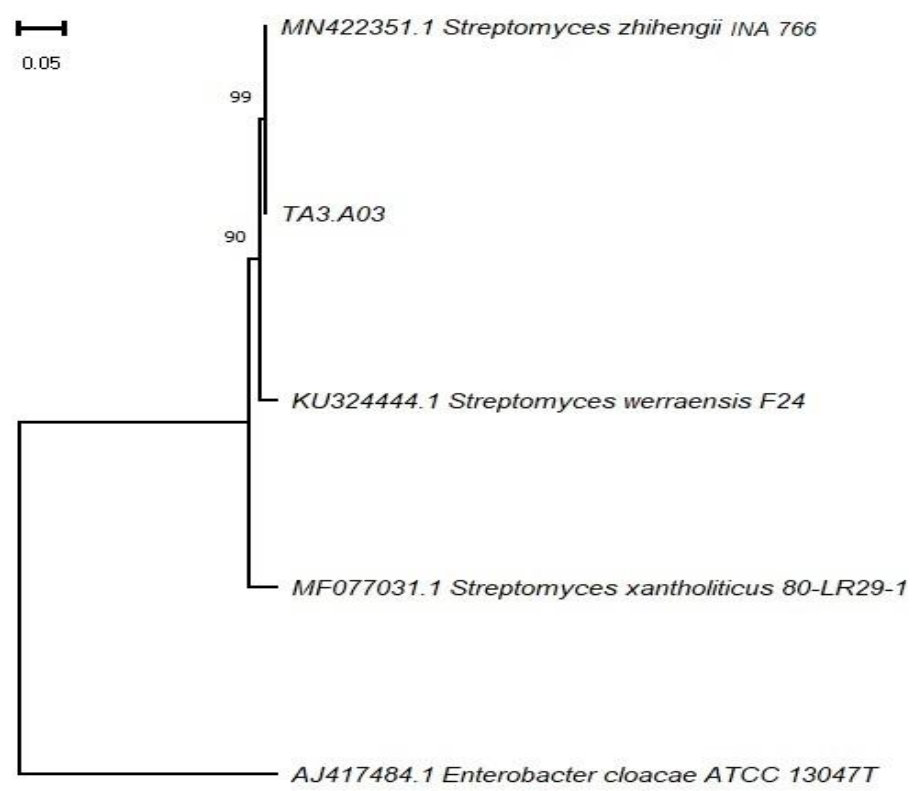

Figure 5. Molecular phylogenetic tree based on the 16S rRNA region sequences of the TA3.A03 strain

Among the genera of marine actinomycetes, the genus Streptomyces is represented in nature by the largest number of species and varieties, which differ greatly in their morphology, physiology, and biochemical activities. Marine Streptomyces occur in different biological sources such as fishes, mollusks, sponges, seaweeds and mangroves, besides seawater and sediments. Based on the physiological, biochemical and chemotaxonomic tests, the actinomycetes was identified as an isolate of Streptomyces sp. TA3.A03. 


\section{Conclusions}

In this study, actinobacteria from marine sediments, strain TA3.A03, exhibited appreciable inhibitory activity against both Gram-positive and Gram-negative bacteria used. The results also showed that strain TA3.A03 was capable of producing extracellular enzymes, such as cellulase, protease, amylase, and lipase. Growth of the isolate occurred in 1-7\% (w/v) $\mathrm{NaCl}$, at pH 5.0-9.0 and $20-45^{\circ} \mathrm{C}$. On the agar plate, the isolate had long spore chains. Aerial mycelium and substrate mycelium were well developed but not fragmented in most media. Based on the biological characteristics and phylogenetic analysis of $16 \mathrm{~S}$ rRNA, it can be hence identified as Streptomyces sp.TA3.A03.

\section{Acknowledgments}

This work is studied in the biotechnology laboratory and financially supported by Vietnam Russia Tropical Centre.

\section{REFERENCES}

[1] M. Cai, X. Y. Zhi, S. K. Tang, Y. Q. Zhang, L. H. Xu and W. J. Li, "Streptomonospora halophila sp. nov., a halophilic actinomycete isolated from a hypersaline soil," International Journal of Systematic and Evolutionary Microbiology, vol. 58, pp.1556-1560, 2008.

[2] M. Donia and M. T. Hamann, "Marine natural products and their potential applications as anti-infective agents," Lancet Infectious Disease, vol.3, pp. 338-348, 2003.

[3] B. Meena, L. A. Rajan, N. V. Vinithkumar, and R. Kirubagaran, "Novel marine actinobacteria from emerald Andaman \& Nicobar Islands: a prospective source for industrial and pharmaceutical byproducts," BMC Microbiology, vol. 13, pp. 145-153, 2013.

[4] H. Tatsuhiko, D. Hideyuki, U. Ichiro, W. Lars, and R. Adhikari, "Global diversity of microbial communities in marine sediment," Proceedings of the National Academy of Sciences of the United States of America, vol. 117, no. 44, pp. 27587-27597, 2020.

[5 P. Solanki and V. Kothari, "Halophilic Actinomycetes: Salt-loving Filaments," International Journal of Life Sciences and Technology, vol. 4, no. 2, pp.7-13, 2011.

[6] K. Duncan, B. Haltli, K. A. Gill, and R. G. Kerr, "Bioprospecting from marine sediments of New Brunswick, Canada: Exploring the relationship between total bacterial diversity and actinobacteria diversity," Marine Drugs, vol. 12, pp. 899-925, 2014.

[7] D. S. Dalisay, D. E. Williams, X. L. Wang, R. Centko, J. Chen, and R. J. Andersen, "Marine sedimentderived Streptomyces bacteria from British Columbia, Canada are a promising microbiota resource for the discovery of antimicrobial natural products," PLOS ONE, vol. 8, pp.1-14, 2013.

[8] U. Managamuri, M. Vijayalakshmi, V. S. Ganduri, S. B. Rajulapati, B. Bonigala, B. S. Kalyani, and S. Poda, "Isolation, identification, optimization, and metabolite profiling of Streptomyces sparsus VSM30," 3 Biotech., vol. 7, no. 3, 2017, doi: 10.1007/s13205-017-0835-1.

[9] T. T. Tran, T. H. Tran, D. H. Chu, P. T. Pham, and V. G. Nguyen, "Characterisation of marine-derived Streptomyces spp. against pathogenic bacteria," Vietnam Journal of Science and Technology, vol. 60, no. 10, pp. 13-17, 2018.

[10] M. Huang, J. J. Fei, N. Salam, C. J. Kim, W. N. Hozzein, M. Xiao, H. Q. Huang, and W. J. Li, "Streptomyces zhihengii sp. nov., isolated from rhizospheric soil of Psammosilene tunicoides," Archive of Microbiology, vol. 198, pp. 743-749, 2016.

[11] M. Madigan and J. Martinko, Brock biology of Microorganisms. Pearson Prentice Hall, New Jersey, 2006, pp. 422-426.

[12] E. Shirling and G. D. Gottlieb, "Methods for characterization of Streptomyces species," International Journal of Systematic and Evolutionary Microbiology, vol. 16, pp. 313-340, 1966.

[13] T. H. N. Vu, Q. H. Nguyen, T. M. L. Dinh, N. T. Quach, T. N. Khieu, H. Hoang, S. C. Ky, T. T. Vu, H. H. Chu, J. Lee, H. Kang, W. J. Li, and Q. T. Phi, "Endophytic actinomycetes associated with Cinnamomum cassia Presl in Hoa Binh province, Vietnam: Distribution, antimicrobial activity and, genetic features," The Journal of General and Applied Microbiology, vol. 66, no. 1, pp.24-31, 2019. 